\title{
Investigating liquidity constraints as a channel of contagion: a regime switching approach
}

\author{
Rajan Sruthi* (D) and Santhakumar Shijin
}

\author{
* Correspondence: sruthi. \\ nellikkathara@gmail.com \\ Department of Commerce, \\ Pondicherry University, Pin, \\ Puducherry 605014, India
}

\begin{abstract}
The present study investigates the timing and repercussion of the subprime crisis of 2008-09 in a regime-switching model. The interdependence and co-movement of financial markets in different countries has been enhanced due to the globalization of international trade, and investment trends can spread globally as a result of investors owning international portfolios. This study uses a regime-switching model to illustrate the timing of the crisis regime and calm regime for United States (US) stock index returns and the corresponding impact on Indian stock index returns. The Indian stocks investigated are classified into "remote" and "reachable" stocks, and different effects are found for these two types. It is found that shocks originating in the US can be transferred to the Indian reachable market as a result of foreign investors. There is, however, a less persistent impact on remote stocks. Accordingly, the study contributes to the literature on the material impacts of the crisis resulting from liquidity constraints and fear of contagion among investors.
\end{abstract}

Keywords: Financial crisis, Financial contagion, Co-movement, Emerging market, Regime- switching

\section{Introduction}

The propagation of a crisis from one country to another can occur in both developed and emerging economies. It generally occurs as a result of a substantial descent in asset prices (Kaminsky et al. 2001; Kyle and Xiong 2001; Yuan 2005). Observations of high volatility in seemingly unrelated economies perplexes researchers and policymakers worldwide (Claessens et al. 2001). The cause of propagation of a financial crisis may be investors' internationally diversified portfolios, whereby liquidity constraints faced by international investors can have repercussions for all markets where they have holdings. In times of crisis, international investors may compensate for the loss in a crisis country by selling stocks they have invested in other markets not affected by the crisis, thus triggering a panic amongst domestic investors. The concept of stock "reachability" for international investors can be used to reflect the potential transmission of a crisis signal to reachable stocks, which can also be compared to the effects observed in relation to "remote" or unreachable stocks (Boyer et al. 2006). Yuan (2005) suggests that

(c) The Author(s). 2020 Open Access This article is licensed under a Creative Commons Attribution 4.0 International License, which permits use, sharing, adaptation, distribution and reproduction in any medium or format, as long as you give appropriate credit to the original author(s) and the source, provide a link to the Creative Commons licence, and indicate if changes were made. The images or other third party material in this article are included in the article's Creative Commons licence, unless indicated otherwise in a credit line to the material. If material is not included in the article's Creative Commons licence and your intended use is not permitted by statutory regulation or exceeds the permitted use, you will need to obtain permission directly from the copyright holder. To view a copy of this licence, visit http://creativecommons.org/licenses/by/4.0/. 
there is a noisy signal of a borrowing constraint, which informed investors receive in terms of asset payoffs. The subsequent price fluctuation observed by uninformed investors' associated with information asymmetry and borrowing constraint seeks a bailout from declining prices and causes crisis to spread to emerging markets. Thus the repercussions of the crisis are not confined to the crisis country: the ripples are observed in other countries as well.

Several stock market crises have occurred in emerging and developed markets over the past few decades, namely, the great depression of 1930, the 1992 exchange rate mechanism crisis, the Mexican Peso crisis in 1994, the 1997 East Asian crisis, the Russian collapse of 1998, the 1999 Brazilian crisis, the 2008-2009 Global Financial Crisis (GFC) and the 2009 European sovereign debt crisis. All these crises emerged in a particular country but had worldwide repercussions (Gallegati 2012; Forbes and Rigobon 2001). Before 1997, the term contagion was used to refer to the transmission of a medical disease. However, the scope of the term broadened since the currency crisis in Thailand. Beginning in July 1997, the Asian financial crisis beset East Asia and elevated the economic meltdown worldwide. The repercussions of the Thailand crisis worldwide initiated the use of the term contagion, specified as financial contagion. After the great depression of the 1930s, the subprime crisis of 2008-09 has been marked as the gravest financial crisis (Bekaert et al. 2014; Claessens et al. 2010; Jaffee 2008; Hwang et al. 2013) affecting the financial markets worldwide (Majid and Kassim 2009). Therefore, the present study concentrates on the 2008-09 subprime crisis as a reference point to investigate the channel of contagion.

The study is closely related to the literature on international transmission of shocks where investor asset holdings are the mechanism through which crises propagate. The theoretical models of portfolio rebalancing (Kodres and Pritsker 2002), wealth constraints (Kyle and Xiong 2001; Calvo 1999; Yuan 2005; Boyer et al. 2006), and information asymmetry (Kodres and Pritsker 2002; Gennotte and Leland 1990; Romer 1993; Hong and Stein 2003; Barlevy and Veronesi 2003) establish the worldwide crisis propagation through the asset holdings of international investors as an antecedent to contagion. Kyle and Xiong (2001) demonstrate the ramifications of a crisis in one country for other countries as the investment loss suffered in the crisis country forcing investors to liquidate their holdings in other countries. Similarly, Kaminsky et al. (2004) and Valdes (1997) show that the crisis affects the liquidity of market participants and propagates it to the other markets. The larger liquidity shock in the crisis country increases credit rationing, thus coercing investors to liquidate their holdings in other countries to meet their margin requirements. Consequently, the asset prices in other countries decline and disseminate the crisis to other markets.

Motivated by Kaminsky et al. (2004), Valdes (1997) and Kyle and Xiong (2001), the present study tries to examine whether the liquidity constraints that emerged at the time of crisis in the United States (US) is accountable for its transmission to the Indian market. First, the present chapter clarifies the theoretical explanation of the propagation of the price drop in one market to another, thus affecting the local investors who are not directly connected to the crisis-prone country. The study investigates how the liquidity constraint emerging in the US affects other assets in the Indian market using a regime switching model. Contrary to the aforementioned studies, the present study adopts a varied attribute to further classify emerging market assets. Namely, stocks are 
classified as "reachable" or "remote" and the regime-switching model is estimated to test the role of the "reachability factor" in terms of how international investors contribute to the propagation of liquidity constraints. The model portrays the movements of reachable stocks, which move in line with US stocks, and also shows the variability of remote stock price movements. Estimating the asymmetry in the persistence of two regimes during the downturns supports the theory of asymmetric contagion, as validated by Longin and Solnik (2001), Connolly and Wang (2000), Ang and Bekaert (2002) and Ang and Chen (2002). Boyer et al. (2006) estimated the cross-market correlation dynamics of the crisis country return with the returns in what they term "accessible" and "inaccessible" assets during the Asian crisis of 1997. However, the present study extends on this research by also estimating the regime shifts from one state to another state (calm to a crisis and crisis to calm). Further, the change in the regimes coupled with the similarities between the crisis country return (US) with the reachable and remote return in the Indian market during the subprime crisis is investigated.

The objective of the study is to estimate the extent of how the crisis in the US motivated international investors to liquidate their holdings in Indian reachable stocks and its recurrent impact on the remote stocks. The extent of the margin calls arising at the time of crisis motivated international investors to sell reachable Indian stocks, in addition to their domestic stocks (i.e., US stocks). The visibly severe price reduction in reachable stocks compelled local investors in India to reduce their holdings in remote stocks as well. As such, the liquidity constraint faced by international investors initiated contagion in domestic markets.

This research enables inferences about the timing of the subprime crisis of 2008-09 to be made and the material side effects of the crisis on the Indian market to be tested based on the reachability factor of Indian stocks to foreigners. Furthermore, testing the material side effects enables the reactions to the crisis in the Indian market to be investigated based on the reachable factor and the corresponding trigger on the remote factor to be further understood. The adoption of a regime-switching model is necessary to detecting the crisis timings for the reachable and remote stocks of the Indian market in relation to the crisis country. The model assumes that, at a point in time, the stock markets in the US is in one of two regimes, crisis or stable. The regime specifically determines the beginning and end of the crisis to develop a model where the movements of the Indian reachable and remote stocks capture the ramifications of the crisis in the Indian Market.

As opposed to other studies on crisis transmission, the novelty of the present study is to capture the extent to which the reachability of Indian stocks to foreign investors determines the crisis transmission. Further, the study investigates whether Indian stocks can signal a crisis event by making a demarcation between reachability factors of Indian stocks to foreigners and investigating reachable and remote stocks separately. While capturing the timing of the crisis impacts on Indian stocks, the study estimates the material side effects of the crisis on Indian reachable and remote stocks in a Markov regime-switching framework.

The remainder of the paper is organized as follows. Section 2 outlines the literature review. Section 3 presents the methodology applied to capture the timing and the side effects of the crisis emanating from the US on the Indian market. Section 4 discusses the empirical interpretations and section 5 concludes. 


\section{Literature review}

The contagion experienced by emerging economies as a result of crises is much more significant than for their developed counterparts (Kodres and Pritsker 2002). Although trade and economic linkages justify the co-movements among the financial markets of different countries, the empirical examinations of Karolyi and Stultz (1996) and Cannolly and Wang (2003) disprove the validity of this idea for American and Japanese markets. To these countries, instead of trade and financial linkages, the shocks to the broad based market indices as global shock underline the positive comovement. A common feature of economic crises is the rapid propagation of crisis substantive events, the financial instability in one country or economy leads to contagion elsewhere.

Reasons for contagion are manifold, ranging from the weak fundamentals in the financial system to crony capitalism (Corsetti et al. 1999). An alternate argument by Radelet and Sachs (1998a, b) and Furman and Stiglitz (1998) suggests that panic is triggered by multi-equilibria amid countries where the shift in investors' expectations by the shocks in one country used as a guideline for other countries. Referring to contagion as the promulgation of market instability, one can observe the co-movement in exchange rates, capital flows, and stock prices as concrete indicators. Conceptually, contagion theories can be classified into two broad paradigms (Claessens et al. 2001). The first of which stresses the effect of spillovers by virtue of normal interdependence among markets (Eichengreen et al. 1996; Glick and Rose 1999; Corsetti et al. 1999, Abeysinghe and Forbes 2005; Forbes 2002; Kali and Reyes 2010, N'Diaye et al. 2010; Chan et al. 2002; Xue et al. 2012; Kaminsky and Reinhart 2000; Van Rijckeghem and Weder 2001, 2003; Baig and Goldfajn 1999). The disturbance which is not caused by changes in macro-economic fundamentals, but instead by the behavior of investors is also considered in terms of the normal interdependence of markets (Boyer et al. 2006; Calvo 1999; Kodres and Pritsker 2002; Kyle and Xiong 2001; Yuan 2005, Rigobon 2003; Masson 1999; Horta et al. 2016; Petmezas and Santamaria 2014). In other words, this school of thought considers the escalation of inherent global or local disturbances across different countries through their real, economic and financial linkages. By contrast, Calvo and Reinhart (1996) avow the transference of crisis as fundamental-based contagion. Studies supporting this fundamental view include Eichengreen et al. (1996), Glick and Rose (1999), Corsetti et al. (1999), Abeysinghe and Forbes (2005), Forbes (2002), Kali and Reyes (2010), N'Diaye et al. (2010), Chan et al. (2002) and Xue et al. (2012) reinstate the argument of contagion through trade linkages. Similarly, Kaminsky and Reinhart (2000), Van Rijckeghem and Weder (2001, 2003) and Baig and Goldfajn (1999) provide evidence for how the financial vulnerability of countries fundamentally moves together. The common shocks effect portrayed by Radelet and Sachs (1998a, b) in their investigation of the Asian financial crisis emphasized the role of financial panic and the withdrawal of foreign capital flows, leading to the depreciation of both real and nominal exchange rates. Considering both the above schools of thought, it is clear that both economic fundamentals and the information of investors have an effect on the stock market. However, there is little consensus in the empirical literature regarding a formal definition of contagion. In accordance with Pericoli and Sbracia (2003), we define contagion as the intensified shift in the transmission channel after a shock in one market. 
The aforementioned studies clearly emphasize fundamental based contagion via trade links (Eichengreen et al. 1996; Abeysinghe and Forbes 2005) common shocks (Calvo and Reinhart 1996; Chuhan et al. 1998), and financial links (Kaminsky and Reinhart 2000; Baig and Goldfajn 1999; Van Rijckeghem and Weder 2001, 2003). The empirical evidence contributes a demarcation between the influence of fundamentals and investors' behavior in causing stock market co-movements. The studies affirm that although fundamental economic effects influence stock market co-movements, the effectual factor causing stock market co-movement contagion is the investors' behavior in the market, which can only be observed indirectly. Karolyi and Stulz (1996) evidenced that macroeconomic announcements and other public information on economic fundamentals influence stock market co-movement between countries. Nevertheless, the major factor influencing co-movements are the shocks to broad-based market indices (Karolyi and Stulz 1996; Connolly and Wang 2003). Similarly, Connolly and Wang (2003) investigated whether observable co-movement in intraday and overnight returns of the international equity markets attribute to public information on economic fundamentals. The results prove that foreign market returns, rather than news announcements, influence domestic market returns. The observation of King et al. (1994) shows a similar result, whereby a small portion of the international stock co-movement is explained by observable economic variables, though admittedly the changes in correlation between the countries are driven primarily by movements in variables which can only be observed indirectly, such as investor sentiment. In addition, Longin and Solnik (2001), Connolly and Wang (2000), Ang and Bekaert (2002), and Ang and Chen (2002) estimated correlation among market returns and showed that correlations are large during market downturns, which suggests that contagion is asymmetric.

These past findings motivate the hypothesis of this research that investors' behavior best explains the stock market co-movements in addition to macro fundamentals. Studies by Kodres and Pritsker (2002), Kyle and Xiong (2001), Calvo (1999), Yuan (2005), Boyer et al. (2006), Rigobon, (2003), Masson (1999), Horta et al. (2016) and Petmezas and Santamaria (2014) shows that investors' stock holdings cause market contagion. Furthermore, a constrained information asymmetry framework describing contagion has been proposed by Gennotte and Leland (1990), Romer (1993), Kodres and Pritsker (2002), Hong and Stein (2003), and Barlevy and Veronesi (2003). Kodres and Pritsker (2002) show that in the absence of news, the shocks in one market are misinterpreted in another market, and this can be interpreted as information asymmetry causing portfolio rebalancing. Apart from this, wealth constrained investors influence stock market co-movements (Kyle and Xiong 2001; Calvo 1999; Yuan 2005) as they liquidate their assets in different markets and thus, large investment losses in the crisis country trigger depreciation in equity prices in other markets as well.

During the past several years, academics have used varied methodologies to investigate the relationships between the stock markets of different countries during the financial crisis. The literature provides evidence of contagion in the financial markets during the 2008-09 subprime crisis (Fry et al. 2010; Idier 2011; Guo et al. 2011; Gallegati 2012; Bekaert et al. 2014; Dungey et al. 2010; Ahmad and Sehgal 2015; Aloui et al. 2011; Lakshmi et al. 2015; Dimitriou et al. 2013; Kenourgios et al. 2013; Jin and An 2016; Kenourgios and Padhi 2012; Kenourgios and Dimitriou 2015; Kenourgios 2014; Leung et al. 2017; Neaime 2016; Guyot et al. 2014; Boamah et al. 2017). More 
specifically, the findings reveal that the magnitude of the stock market linkage tends to be higher in crisis periods (Yang et al. 2003; Yang et al. 2006), whereby the highest number of contagion incidents occur in developed markets (Baur 2012; Calomiris et al. 2012) and the incidents propagate to smaller economies (Breuss 2011; Karunanayake et al. 2010; Kenourgios et al. 2011).

There is also an extensive body of literature on financial contagion which measures the volatility spillovers among markets. For example, Calvo and Reinhart (1996) used the principal component models, Glick and Rose (1999) adopted the spillover model, Baur (2003) used regression-based models of asymmetries and non-linearities and finally, models of interdependence were applied by Bekaert et al. (2005). Similarly, Bertero and Mayer (1990), King and Wadhwani (1990), Calvo and Reinhart (1996), Baig and Goldfajn (1999) and Hon et al. (2007) employed correlation breakdown models. However, Forbes and Rigobon (2002) highlighted a number of limitations in the literature on financial contagion with the prior methods, such as heteroskedasticity problems and omitted variables in measuring correlations.

Motivated by the thought-provoking study by Forbes and Rigibon (2002), the recent literature on financial contagion employs methodologies such as models based on extreme value theory (Longin and Solnik 2001; Hartman et al. 2004; Bae et al. 2003; Butler and Joaquin 2002; Chan-Lau et al. 2004), autoregressive conditional heteroscedasticity (ARCH) models (Hamao et al. 1990), Markov switching models (Ramchand and Susmel 1998; Ang and Bekaert 2002; Chesney and Jondeau 2001; Pelletier 2006; Guo et al. 2011; Mandilaras and Bird 2010; Billio et al. 2005; Gravelle et al. 2006), dynamic copulas with or without regimes (Rodriquez 2007; Okimoto 2008; Aloui et al. 2011; Jondeau and Rockinger 2006; Patton 2006, 2009; Chollete et al. 2011; Ning 2010; Sun et al. 2009), conditional asymmetries and correlations models like Dynamic Conditional Correlations (DCC) using GARCH (Celik 2012; Chiang et al. 2007), Fractionally Integrated Asymmetric Power ARCH (FIAPARCH) models (Kenourgios and Dimitriou 2015; Dimitriou et al. 2013), the Asymmetric Generalized DCC (AG-DCC) model (Cappiello et al. 2006) and a multivariate regime-switching Gaussian copula model and the AG-DCC model (Kenourgios et al. 2011). Further, studies by Kou et al. (2019) and Chao et al. (2019) adopted machine learning methods to study the mechanisms of outbreak and the contagion of systemic risk in the financial market network. Many of the aforementioned studies emphasize that the choice of methodology is important when investigating abnormal behavior in financial markets.

Ang and Bekaert (2002) and Ang and Chen (2002) investigate stock market comovements to see whether market co-movement is stronger in market downturns and find evidence of asymmetric contagion. Ang and Bekaert (2002) studied international asset allocation with regime shifts to see whether the existence of high volatility in a market downturn regime invalidates the benefits of international diversification. Using a regime-switching model, the results validate international diversification where investors can dynamically make portfolio decisions in response to the regime switches. Further, the existence of highly volatile bear market regimes does not invalidate the benefits of international diversification; rather it suggests that a switch toward lower volatility assets may be advisable. Similarly, Ang and Chen (2002) studied the correlation asymmetry between US stocks and the aggregate US market in downside and upside moves to understand the consequences for portfolio allocation. Comparing the 
GARCH-in-Mean (GARCH-M) model, Poisson Jump model, Regime switching normal distribution model and Regime switching GARCH model on the asymmetric correlation of stock returns, Ang and Chen (2002) evidenced that the regime-switching normal distribution model is the best to model the correlation asymmetries. The authors also find that correlations between markets are stronger during market downturns, thus showing contagion. Similarly, Baele (2005) investigated the effect of globalization and regional integration in transmitting global shocks to local markets. Using a regimeswitching model, the study allows the shocks intensities to change over time and the authors found evidence of contagion from US markets to the European markets in terms of an increased probability of switching from one market to another at times of high market volatility.

In addition to the studies investigating the propagation of crises, there are studies investigating the impact of policy interventions and regulatory measures on the level and rapidity of cross and within country contagion. Kosmidou et al. (2015) and Kosmidou et al. (2019) investigated the effectiveness of policy interventions from the European Union/European Central Bank/International Monetary Fund (EU/ECB/IMF) to prevent contagion across European member states. During medium to high volatility periods, the news announcements concerning policy interventions by the ECB, EU, and IMF decrease the speed of contagion from banking-specific news spreading to both the stock market and the industrial sector. On the other hand, the policy news announcement by national governments decelerate the contagion from banking only for the industry sector and not for the overall stock market. In short, the simultaneous release of policyrelated news of the ECB, EU, IMF, and the national governments seems to be beneficial in reducing contagion.

The present study uses a different attribute of emerging stock markets to investigate how liquidity constraints during crisis motivate investors to liquidate their positions in other markets, whereby the reachable and remote factors are applied to reflect the accessibility of stocks to international investors. Using the regime-switching model of Hamilton (1989), this study illustrates international investors' motivation in liquidating their holdings of reachable stocks in the Indian market, thus transmitting shocks to Indian stocks. Defining Indian stocks as reachable, if they are accessible to international investors, and remote, if they are not, we try to capture to what extent investors influence contagion as a result of their liquidity constraints. The regime-switching model further identifies the duration for which returns are affected in different regimes of calm and crisis.

\section{Methodology}

The time series variables are subject to periods of dramatic changes to their usual trends. A dramatic change in macroeconomic or financial time series variables is likely to reflect financial panics, wars, or other sudden changes in the market. The regimeswitching model is an effective means of modeling dramatic changes in a time series. In this paper, we investigate the special case developed by Hamilton (1989). Specifically, we investigate the shift in stock index returns occurring on the basis of either the calm or crisis regime, respectively. The regime at any given date can be considered to be the outcome of a Markov chain, for which the realizations are unobserved. Characterizing the two regimes and the law governing the transition between the two regimes is the 
task of the regime-switching model. The parameter estimates reflect the regime process on any particular date and enable forecasts of future values to be generated.

A single variable $r_{t}$, stock index return, is modeled to quantify the outcome of a dramatic change in the behavior of the time series under investigation. The change in the time series data prior to a crisis (i.e., in a calm regime) and during a crisis (i.e., in a crisis regime) is modeled. The typical historical behavior is modeled with first-order autoregression, whereby the data prior to the crisis is modeled as

$$
r_{t}=\mu_{0}+\phi r_{t-1}+\varepsilon_{t}
$$

where $\varepsilon_{t} \sim N\left(0, \sigma^{2}\right)$ and the observed data for $t=1,2, \ldots, t_{0}$. The model assumes that at date $t_{0}$, the time series undergoes significant change. The significant change in the average level of the series at date $t_{0}$ following a crisis is described by the model as

$$
r_{t}=\mu_{1}+\phi r_{t-1}+\varepsilon_{t}
$$

According to the model for $t=t_{0}+1, t_{0}+2, \ldots$.

Where $t$ in eq. $(1,2)$ explain the data prior to and after the crisis respectively. An evaluation in to the data for $t$ in eq. (2) compared with (1) necessitates the significant change observed to the time series following the crisis.

However, these two models are not satisfactory as a time series model for this context. Changing the intercept from $\mu_{0}$ to $\mu_{1}$ enhance the forecast accuracy but this is not sufficient. Thus, instead of relying on the change from $\mu_{0}$ to $\mu_{1}$, the model also assumes that an imperfectly predictable force produces this change. In other words, the change itself is considered as a random variable. Hence, instead of just considering model (1) and (2) expressing data up to date $t_{0}$ and postdate $t_{0}$, we adopted a complete time series model describing the probability law governing the change from $\mu_{0}$ to $\mu_{1}$. This approach more accurately describes the consequences of a dramatic change in the behavior of the variable $r_{t}$. The model below encompasses both the aforementioned models:

$$
r_{t}=\mu_{s_{t}}+\phi r_{t-1}+\varepsilon_{t}
$$

The defined switch from $\mu_{0}$ to $\mu_{1}$ assumes that there are two possible regimes, namely zero and one, from which a particular observation of $r_{t}$ is drawn. This unobserved random variable is known as the "state" of the process. The unobserved state is denoted by $s_{t}$, which takes an integer value of either 0 or 1 . The random variable $s_{t}$ assumes the value $s_{t}=0$ for $t=1,2, \ldots, t_{0}$ and $s_{t}=1$ for $t=t_{0}+1, t_{0}+2, \ldots$.

Here, the number of variables is one, the autoregressive lag order is one, the number of possible regimes is two and the model assumes that $r_{t}$ depends on the current and most recent values of $s_{t}$, on lags of $r_{t}$, and on a vector of parameters, $\theta$. Thus, the probability of a regime prevailing is $p\left(r_{t} \mid z_{t} ; \theta\right)$.

where $z_{t}=\left(s_{t}, s_{t-1}, r_{t-1}\right)$.

This model is an extension of the model developed by Hamilton (1989), in which Engel and Hamilton (1990) evaluated the vector systems without autoregressive elements, such that $\phi=0$. The model shows that the mean vector and the variance matrix were functions of the state, which is defined as follows:

$$
r_{t} \mid s_{t} \sim N\left(\mu_{s_{t}}, \sigma_{s_{t}}^{2}\right), s_{t}=0,1 \text {. }
$$

The model proposes the existence of an unobservable variable, $s_{t}$, which portrays the state or regime the event was in at date $t$ by assigning the value of zero or one. When 
the unobserved variable $s_{t}=0$, the noticeable change in the variable $r_{t}$ is assumed to have been drawn from the $N\left(\mu_{0}, \sigma_{0}^{2}\right)$ distribution. When $s_{t}=1$, the variable $r_{t}$ is distributed as $N\left(\mu_{1}, \sigma_{1}^{2}\right)$. Therefore, when $s_{t}=0$, the mean vector is $\mu_{0}$ and when $s_{t}=1$, it is $\mu_{1}$.

Here, the number of variables is one namely the stock index returns of the respective series, the autoregressive lag order is zero, number of possible regimes is two, and the model assumes that $r_{t}$ depends only on the current values of $s_{t}$ and on a vector of parameters, $\theta$. Thus, the probability of a regime switch is.

$p\left(r_{t} \mid s_{t} ; \theta\right)$, where $\theta=\left(\mu_{0}, \mu_{1}, \sigma_{0}^{2}, \sigma_{1}^{2}\right)$.

A probabilistic model showing the change from $s_{t}=0$ to $s_{t}=1$ gives a complete description of the probability law governing the observed data. The two-state Markov chain clearly specifies that $s_{t}$ is a realization of the two-state options with a transition probability. This can be represented as:

$$
p\left(s_{t}=j \mid s_{t-1}=i\right)=p_{i j}
$$

Following Hamilton (1989) and Engel and Hamilton (1990), the Markov chain for the evolution of the unobserved state variable is given by;

$$
\begin{aligned}
& p\left(s_{t}=0 \mid s_{t-1}=0\right)=p_{00}, \\
& p\left(s_{t}=1 \mid s_{t-1}=0\right)=p_{01}, \\
& p\left(s_{t}=0 \mid s_{t-1}=1\right)=p_{10}, \\
& p\left(s_{t}=1 \mid s_{t-1}=1\right)=p_{11},
\end{aligned}
$$

(Thereby,)

$$
p=\left(p_{00}, p_{01}, p_{10}, p_{11}\right) .
$$

It is presumed that the process for $s_{t}$ depends on the past realizations of $r$ and $s$ only through $s_{t-1}$. In the model, the unobservable variable $s_{t}$ is not directly observed. Instead, it is deduced based on the observed behavior of $r_{t}$. The parameters which describe the probability law governing $r_{t}$ are the variances $\sigma_{0}^{2}$ and $\sigma_{1}^{2}$, the autoregressive coefficient $\phi$ (with or without autoregressive dynamics), the two intercepts $\mu_{0}$ and $\mu_{1}$, and the two state transition probabilities $p_{00}$ and $p_{11}$.

The parameter estimates of the model give the smoothed regime probabilities based on the full sample. Thus, the probability with which a regime is supposed to have transpired at each time can be determined. The peaks and troughs of the data in the series can be determined. However, in our model, the smoothed regime probabilities, which aim to capture the real timings of the crisis, were allowed to follow regime specific error variance, which was assumed to be constant across regimes. Therefore, the model as includes a constant error variance, $\sigma^{2}$, along with the means of $\mu_{0}, \mu_{1}$ and the transition probability $p_{00}$ and $p_{11}$.

\section{Data}

We study the daily stock index returns of reachable and remote stocks for US investors over the period from April 2007 to June 2016. The classification of reachable and remote stocks applies to Indian stocks. In the developed market, all stocks are reachable to both foreign and local investors but this is not the case with emerging markets. The International Finance Corporation (IFC) publishes the IFC investable (IFCI) stock index 
series for each of the emerging markets. The IFCI index determines the legal market openness to foreign investors by screening stocks according to size and liquidity. The size and liquidity requirement is dependent on a base market capitalization of $\$ 50$ million or more and a base trading volume of $\$ 20$ million or more before 12 months stocks accession to the IFCI index. The readily available return information for the IFCI index typifies the reachable stock market index in terms of what foreign investors would receive from investing in the Indian market. The NSE 500 index is used as a proxy for the whole market. All the stocks from the global portfolio that are not in the IFCI index are included in the remote index, which represents those stocks which are only reachable for Indian investors. Specifically, the remote index has been constructed following Boyer et al. (2006), considering NSE 500 as the proxy for the Indian total index and IFCI as follows:

$$
R_{R m t s, t}=M_{I s, t-1} \times R_{I s, t}-M_{R c h s, t-1} \times R_{R c h s, t} /\left(M_{I s, t-1}-M_{R c h s, t-1}\right)
$$

Here, $R$ represents index returns, $M$ is index market capitalization, $I s, R c h s$ and $R m t s$ refers to the Indian, reachable and remote stock index respectively and $t$ denotes the time period.

The data have been compiled from the Bloomberg database. The regime-switching model estimates detect the timing, as well as the side effects of the crisis among Indian investors.

\section{Empirical results and interpretation}

This study investigates the side effects of the global financial crisis of 2008-09 on the Indian market. Past studies have delineated various timelines to determine the timing of the crisis in the US (Bank for International Settlements (BIS) 2009; Federal Reserve Board of St. Louis 2009; Guillen 2009). The present study tries to capture the timing of the crisis to adduce its side effects, focusing on liquidity constraints, on the Indian economy. The unobservable state of financial calm and crisis regime is modeled using a regime-switching model.

Figures 1, 2 and 3 show the Markov switching model of heteroscedasticity, as defined by Kim et al. (1998), for stock index returns of US stocks, reachable Indian stocks and remote Indian stocks.

Figures 1, 2 and 3 and the corresponding Table 1 reveal the non-normal unconditional sampling distribution, thus confirming the presence of skewness and excess kurtosis in the data. This is to be expected based on the findings of Fama (1963) and Mandelbrot (1963). The marked values and statistics showing the peak and heavy tails in the distribution of the stock index returns evidences the need to consider heteroscedasticity (Turner et al. 1989). The popularly adopted specification in the study of stock return volatility or heteroscedasticity is the GARCH model by Engle (1982) and Bollerslev (1986). However, the SWARCH (switching ARCH) model proposed by Hamilton and Susmel (1994) allow parameters of an ARCH process to be defined differently for different regimes in a regime-switching model. This effectively addresses the heteroscedasticity in stock index returns. Following Engel and Hamilton (1990), this study considers the below two-state regime switching model of stock index returns.

$$
r_{t} \mid s_{t} \sim N\left(\mu_{s_{t}}, \sigma^{2}\right), s_{t}=0,1 \text {. }
$$




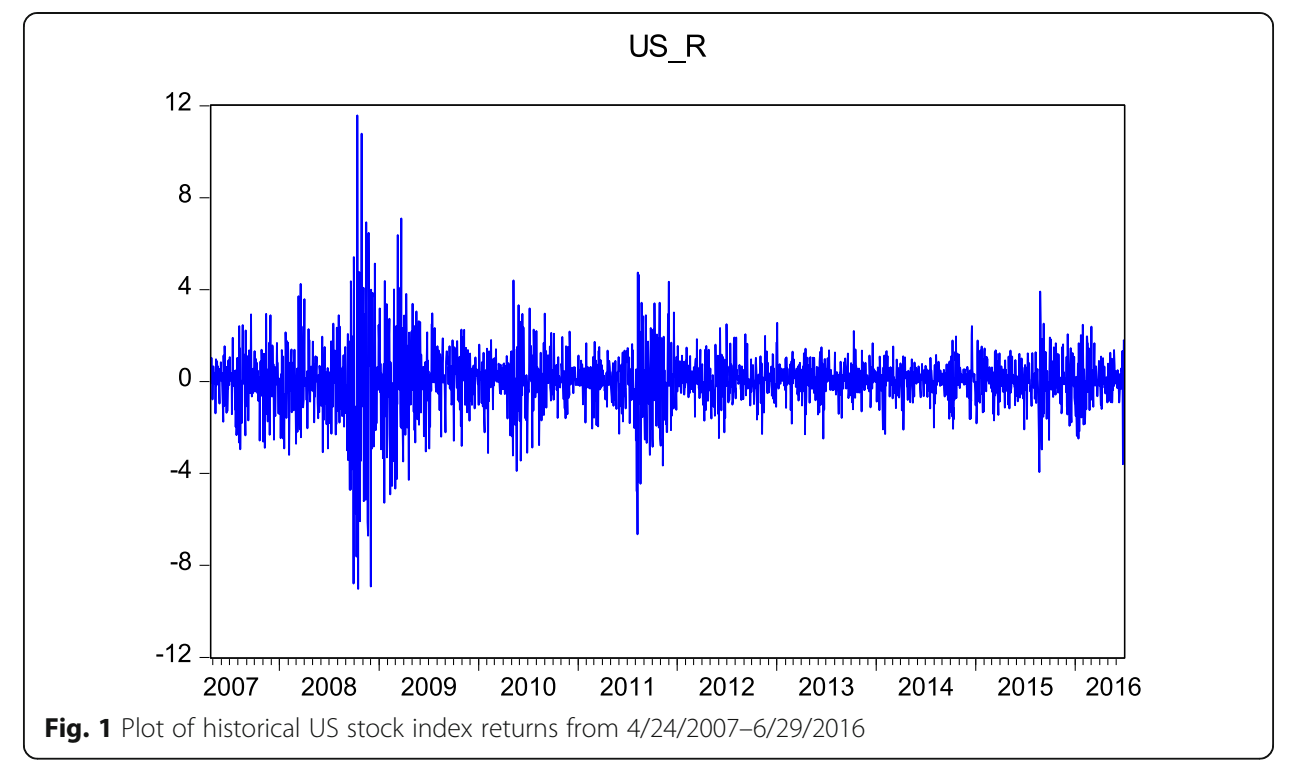

The model assumes that $r$ depends only on the current values of $s_{t}$ and on a vector of parameters, $\theta$.

Thus, the probability of a regime prevailing is $p\left(r_{t} \mid s_{t} ; \theta\right)$.

where $r \cong u s r$, irchr, irmtr which is the stock index returns for the three series of US (usr), Indian reachable (irchr) and Indian remote stocks (irmtr).

Here, $s_{t}$ is the unobserved variable that takes the value of zero or one and characterizes the state or regime the event was in at date $t$. When $s_{t}=0$, the observed change in the variable $r_{t}$, namely the usr, irchr, irmtr values, are presumed to be drawn from the $N\left(\mu_{0}, \sigma_{0}^{2}\right)$ distribution and when $s_{t}=1$, the observed change in the variables $u s r$, irchr, irmtr are presumed to be drawn from the $N\left(\mu_{1}, \sigma_{1}^{2}\right)$ distribution. Therefore, the model assumes that the variable returns depend on the current values of $s_{t}$ and on a vector of parameters, $\theta$, which is defined as follows:

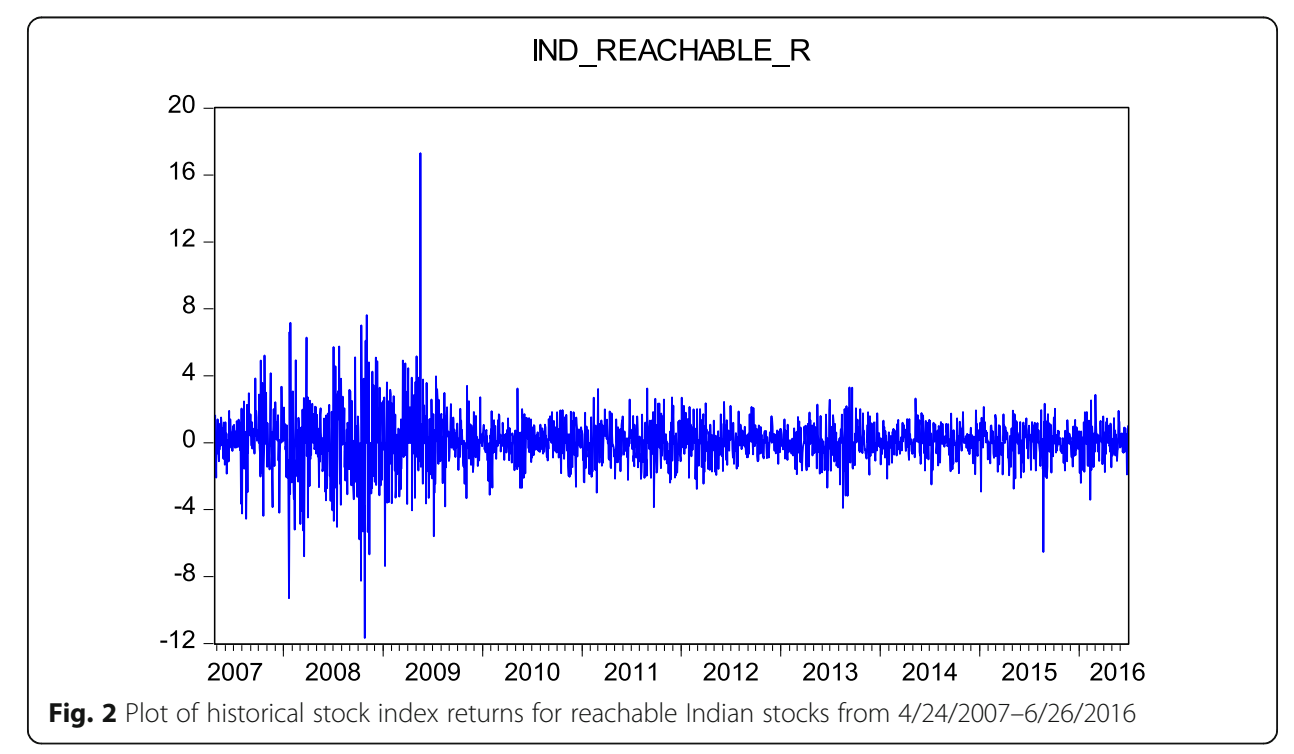




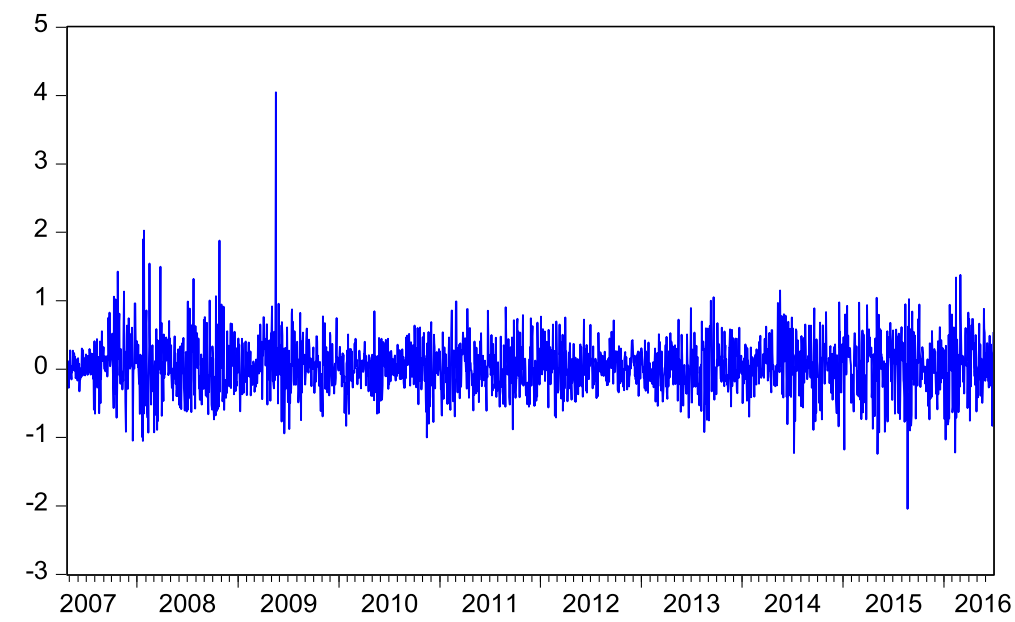

Fig. 3 Plot of historical stock index returns for remote Indian stocks from 4/24/2007-6/29/2016

$$
\theta=\left(\mu_{0}, \mu_{1}, \sigma_{0}^{2}, \sigma_{1}^{2}\right) .
$$

The Markov chain shows the transmission probabilities for the change from $s_{t}=0$ to $s_{t}=1$, thereby giving a complete description of the probability law governing the observed data. The two-state Markov chain clearly specifies that $s_{t}$ is a realization of the two-states, with the following transition probability:

$$
p\left(s_{t}=j \mid s_{t-1}=i\right)=p_{i j} .
$$

Following Hamilton (1989) and Engel and Hamilton (1990), the Markov chain for the evolution of the unobserved state variable is given by:

$$
\begin{aligned}
& p\left(s_{t}=0 \mid s_{t-1}=0\right)=p_{00}, \\
& p\left(s_{t}=1 \mid s_{t-1}=0\right)=p_{01}, \\
& p\left(s_{t}=0 \mid s_{t-1}=1\right)=p_{10}, \\
& p\left(s_{t}=1 \mid s_{t-1}=1\right)=p_{11},
\end{aligned}
$$

for which,

$$
p=\left(p_{00}, p_{01}, p_{10}, p_{11}\right) .
$$

\begin{tabular}{|c|c|c|c|c|c|c|}
\hline SI. No: & Variables & Mean & Median & Std. Dev & Skewness & Kurtosis \\
\hline 1 & US Return & 0.035685 & 0.075576 & 1.353654 & -0.069699 & 12.44939 \\
\hline 2 & Indian Reachable Return & 0.045814 & 0.025035 & 1.477971 & 0.231311 & 16.04324 \\
\hline 3 & Indian Remote Return & 0.041719 & 0.038470 & 0.374275 & 0.663970 & 9.854970 \\
\hline
\end{tabular}

As noted above, the stock index returns for the three series of US (usr), Indian reachable (irchr) and Indian remote stocks (irmtr) are represented by $r$. As $s_{t}$ is a random variable, the incidence of changes to the stock index returns occur in the time series to infer the value $s_{t}=0$ and $s_{t}=1$ for calm and crisis regimes, respectively. Here, $\mu_{0}$ and $\mu_{1}$

Table 1 Descriptive statistics 
are the means of the stock index returns for the calm and crisis regimes. However, the present study tries to capture the real timings of the crisis, without considering regimespecific error variance. In other words, the error variance is assumed to be constant across regimes. Therefore, the parameters required to estimate $\theta$ are restricted to $\mu_{0}$, $\mu_{1}, \sigma^{2}, p_{00}$ and $p_{11}$.

The side effects of the subprime crisis on reachable and remote stocks of the Indian economy were analyzed with the corresponding decade-long changes in trends. The parameter estimates of the regime switching model considered constant transition probabilities and the Markov probabilities that represent the unconditional probabilities of a change in regime. The state variable $s_{t}$ in the model follows a two-state Markov chain, clearly specifying that $s_{t}$ is a realization of one of the two-states, with constant transition probability, namely $P\left(s_{t}=j \mid s_{t-1}=i\right)=p_{i j}$ whereby $(i, j=0,1)$.

Table 2 shows the estimation result of the regime switching model. The transition probabilities of the US stock index returns, Indian reachable and remote stock index returns during financial calm and crisis periods are estimated through $p_{00}$ and $p_{11}$. In the case of US stock index returns, the state at $t-1$ was the calm state $\left(s_{t-1}=0\right)$, with a $15 \%$ chance that time $t$ will also be a calm state $\left(s_{t}=0\right)$. This is notated as $P\left(S_{t}=0 \mid S_{t}\right.$ $-1=0)=p_{o o}$. On the contrary, if the state at the time $t-1$ is the crisis state $\left(s_{t-1}=1\right)$, then there is a $98 \%$ chance that the state at time $t$ will also be a crisis state $\left(s_{t}=1\right)$, noting that $P\left(S_{t}=1 \mid S_{t-1}=1\right)=p_{11}$. This indicates that the probabilities of being in a calm or a crisis state are approximately $15 \%$ and $98 \%$, respectively, which suggests there is no considerable state dependence in terms of staying in the original state of financial calm for an extended period of time. There is an $85 \%$ chance of transition probabilities to switch from a calm regime to a crisis regime for the US index returns since the inception of the financial crisis from July 2008 to May 2009. Investigating Indian reachable stocks, if the state at $t-1$ was a calm state $\left(s_{t-1}=0\right)$, then there is a $25 \%$ chance that state at the time $t$ will also be a calm state $\left(s_{t}=0\right)$, which is notated as, $P\left(S_{t}=0 \mid S_{t}\right.$ $-1=0)=p_{o o}$. On the contrary, if the state at the time $t-1$ was crisis state $\left(s_{t-1}=1\right)$, then results show that there is a $98 \%$ chance that the state at time $t$ will also be crisis state $\left(s_{t}=1\right)$, whereby, $P\left(S_{t}=1 \mid S_{t-1}=1\right)=p_{11}$. Similarly, for remote stock index returns, if the state at $t-1$ was a calm state $\left(s_{t-1}=0\right)$, then results show that there is a $6 \%$ chance that state at time $t$ will also be a calm state $\left(s_{t}=0\right)$, which again is notated as $P\left(S_{t}=0 \mid S_{t-1}=0\right)=p_{o o}$. Further, if the state at time $t-1$ was a crisis state $\left(s_{t-1}=1\right)$, results show that there is a $99 \%$ chance that the state at time $t$ will also be crisis state $\left(s_{t}=\right.$ 1), thereby $P\left(S_{t}=1 \mid S_{t-1}=1\right)=p_{11}$.

Table 2 Parameter estimates for Markov Regime-Switching Model from April 2007 to June 2016

\begin{tabular}{llll}
\hline Parameter & $\begin{array}{l}\text { Unites States } \\
\text { Crisis Return }\end{array}$ & Reachable Return & \\
\cline { 4 - 4 } & 0.1501 & 0.2546 & Remote Return \\
\hline$p_{00}$ & 0.9875 & 0.9884 & 0.0593 \\
$p_{11}$ & -4.9414 & -4.9776 & 0.9967 \\
$\mu_{1}$ & $(0.3428)$ & $(0.3504)$ & 1.9702 \\
& 0.1083 & 0.1238 & $(0.2080)$ \\
$\mu_{0}$ & $(0.0257)$ & $(0.0281)$ & 0.0355 \\
& 0.1925 & 0.2914 & $(0.0074)$ \\
$\sigma^{2} \sigma^{2}$ & $(0.0158)$ & $(0.0160)$ & -1.0275 \\
& & & $(0.0151)$ \\
\hline
\end{tabular}

Standard error values in parenthesis 
The Indian reachable and remote stocks also do not show any state dependence in terms of staying in one regime for a long time. Since in the scenario of the subprime crisis, the transition probabilities for switching from a calm regime to a crisis regime increases to $98 \%$, thus evidencing a comparatively $85 \%$ chance of transition probabilities to switch from calm to crisis regime for US stock index returns. The disruption to the Indian market during the subprime crisis is evidenced by a shift to a crisis regime, which is reflected in the time series of conditional transition probabilities. The constant transition probability shows the expected duration of stay in the regime for the respective indices.

The estimated means of the growth rate of the US stock index returns in the calm state is 0.1083 . On the other hand, it falls to $-4.8331\left(\mu_{0}+\mu_{1}\right)$ in the crisis state. This shows that, during the subprime crisis period, the US stock index returns fell by an average of $4.83 \%$ per day. Similarly, the estimated mean of the growth rate of the Indian reachable stock index returns in the calm state is 0.1238 . However, in the crisis state, the estimated mean growth rate of the Indian reachable stock returns falls to -4.8537 $\left(\mu_{0}+\mu_{1}\right)$. This means that, during the subprime crisis period, the Indian reachable stock index returns also falls by an average of $4.85 \%$ per day. In contrast, the estimated mean of the growth rates of the Indian remote stock index returns in the calm state is 0.0355 but in the crisis state, the mean raises to 2.0057. This implies that, during the subprime crisis period, the Indian remote stock index returns rise by an average of $2.00 \%$ per day. The less significant oscillation of remote stocks between crisis and calm periods explains this effect. The negative growth rate of the US stock index returns and the reachable stock index returns are consistent with the state of a crisis regime. Conversely, the remote stocks positive growth rate, despite the crisis regime, suggests that while reachable stocks were affected by the crisis, its impact on the remote stocks is not clearly visible.

In addition, the model sheds light on a variety of behaviors. In particular, it allows for asymmetry in the persistence of the two regimes, exemplifying that the regimes are stronger in market downturns (Engel and Hamilton, 1990). The large and positive $\mu_{0}$ $(0.1083,0.1238$ and 0.0355$)$ and small constant transition probability $p_{00}(0.1501$, 0.2546 and 0.0593 ) shows that the upward moves (calm regime) are short but sharp. Likewise, the negative and small values of $\mu_{1}(-4.9414,-4.9776$ and 1.9702) and the large constant transition probability $p_{11}(0.9875,0.9884$ and 0.9967$)$ reveals that the downward moves (crisis regime) are gradual. This exemplifies asymmetric behavior for the US, Indian reachable and remote returns. Crises initiated in the US affect the Indian reachable market in a similar manner, and thus the resulting contagion is asymmetric.

Figures 4, 5 and 6 show the estimated smoothing probabilities of the shift in regime from a state of calm to crisis. The regime-switching model assumes that the disruptions of a crisis in time series shift regimes from one state to another, which can be represented by a series of conditional probabilities. The figures point out the timings of the crisis, as well as the conditional probability of the financial crisis, which jumps from zero to one during 2008-09 in the regime-switching model. The smoothed regime probabilities infer ex-post in which state the returns are at each time and also reflect the recurrent regime shifts in stock index returns. This analysis can be conducted based on estimates of the transition probabilities. 


\section{Smoothed Regime Probabilities \\ $P(S(t)=1)$}

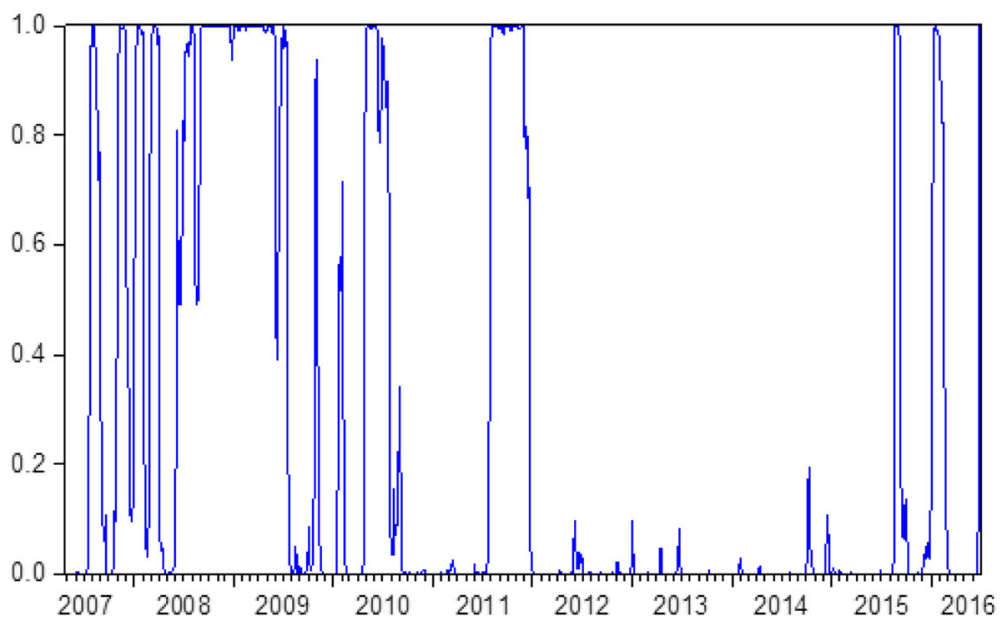

Fig. 4 Smoothed Regime Probabilities of US Stock Index Returns

Figure 4 shows a shift between a crisis regime and a calm regime between 2007 and 2008 for the US index returns. From 2008 onwards, the state of crisis regime persists, with a shift in the series that lasts for a period of 1 year until 2009. More specifically, for the US, the period of the crisis regime from 8/06/2008 is maintained with the probability close to one until $5 / 21 / 2009$. The shift to a calm regime is exemplified by the regime probability returning to close to zero by $7 / 29 / 2009$. Hence, the figure exemplifies cogent shifts in the US Stock index returns in the subprime crisis period.

Figure 5 shows the smoothed regime probabilities of Indian reachable stock index returns through the period 2007 to 2016. In accordance with US index returns, Indian reachable index returns show a consistent shift of the state through the period 2008 to

\section{Smoothed Regime Probabilities}

$P(S(t)=1)$

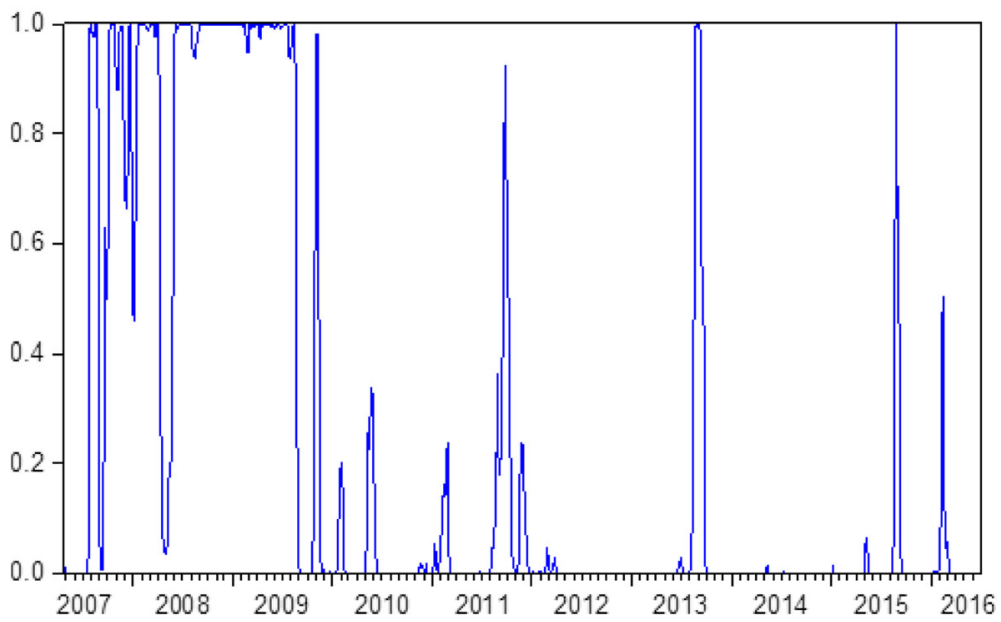

Fig. 5 Smoothed Regime Probabilities of Indian Reachable Stock Index Returns 
Smoothed Regime Probabilities

$P(S(t)=1)$

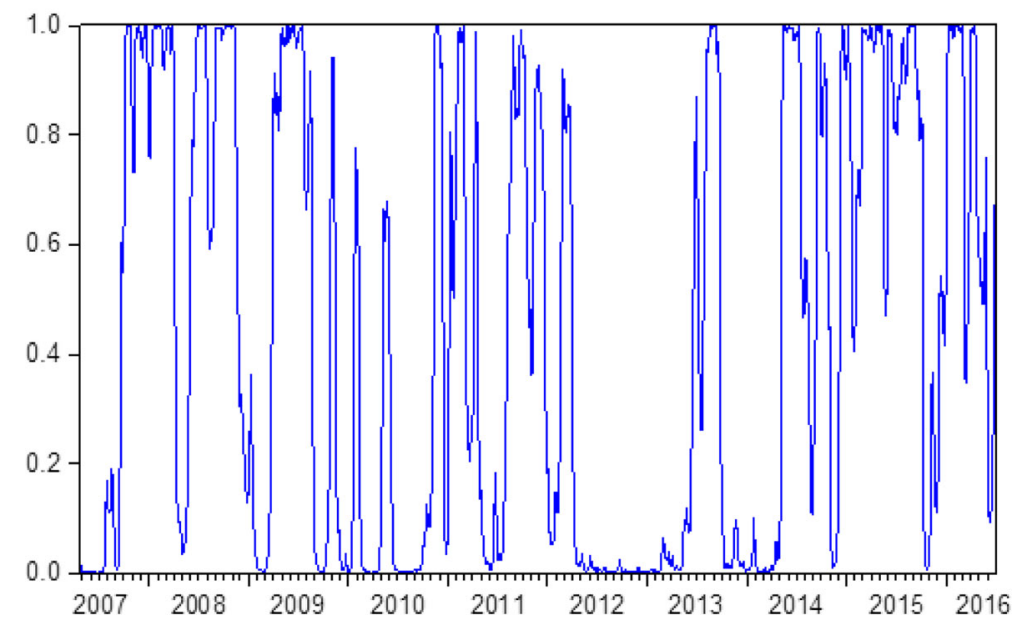

Fig. 6 Smoothed Regime probabilities of Indian Remote Stock Index Returns

2009. The figure for the US Index returns exemplified the crisis period for the US market. The reachability of Indian stocks to the US market suggests that the fear of crisis transmission as a result of its reachability factor is justified. The regime-switching model of the reachable Indian stock returns mirrors the start and the end of the US crisis regime. Following the commencement of the subprime crisis of the US, the conditional probability of a crisis regime for Indian reachable stocks jumps to one in 6/12/ 2008. This scenario lasts for one year and by $9 / 08 / 2009$, is the probability returns to close to zero, which evidences that the crisis of 2008-09 in the US had a similar effect on the Indian reachable stocks. One possible explanation for this is that, to make up the margin call needs that emerged at the time of the US crisis, investors were compelled to sell Indian stocks where they have reachability. This would ultimately lead to a price decline in Indian reachable stocks, which suggests that the fear of contagion for the Indian reachable market is justified. Finally, this study investigates whether this impact persists only for the reachable stocks or whether it also has an impact on the Indian remote stocks.

The smoothed regime probabilities of the Indian remote stock index returns through 2007 to 2016 reported in Fig. 6 show mixed events of regime shifts. During the time of the crisis in the US, Indian remote stocks have a tendency to move to a crisis state for a limited period of time and then return back to the calm state for a limited duration. The influence on reachable Indian stocks can be expected to have an automatic impact on remote stocks. This might be a cause for the remote stocks to oscillate between calm and crisis regimes of a short duration. A period of crisis transition occurs from 5/ $05 / 2008(0.04)$ to $6 / 26 / 2008$ (.99). On $6 / 26 / 2008$, the Indian remote stocks reach a crisis regime following the sudden shift beginning on 5/05/2008. As of this point, the series shows a tendency to move to the calm regime, but again reaches a crisis on $8 / 08$ / 2008 (0.59). The probability of the crisis regime being maintained reaches one on 9/16/ 2008 and the remote stocks remain in the crisis regime until 11/11/2008. A similar shift is observed approximately every four months. This suggests that the regimes of remote 
stocks are stagnant, as is the case for the reachable stocks. More specifically, the crisis impact on the Indian reachable stocks exemplifies a similar scenario to the US Index returns and the remote stocks show that the impact of the crisis is short-term in nature and regime shifts with a short duration can be observed.

This study contributes to the empirical literature on investor-influenced contagion as a result of liquidity constraints on international investors. International investors acting to liquidate their holdings in other markets as a result of a crisis in their home market leads to increased price volatility in both markets and an automatic crisis effect is reflected in the other market. Consequently, the Indian reachable stocks show a predilection for following crisis regime movements from the US market. The remote stocks also show a tendency to move to a crisis regime at the same time, but they also oscillate back forth between crisis and calm regimes in consecutive periods.

\section{Conclusion}

The paper explores the timings of the crisis as well as its side effects on Indian reachable and remote stocks to validate the hypothesis that liquidity constraints on investors influenced contagion at the time of the 2008-09 financial crisis. The subprime crisis of 2008-09, which was initiated in the US, is investigated to assess its impact on the Indian market due to liquidity constraints emerging from the reachability factor. The reachability factor suggests that the Indian stocks' reachability to international investors provided a means for them to meet their liquidity constraints. The regime switching model, which accounts for the non-normal unconditional heteroscedasticity of the stock index returns, finds evidence consistent with a regime change occurrence for the respective series of stock index returns. The estimated probabilities over the state of the regime model suggest that, although the global crisis began in 2007, the lasting tendency to stay in the crisis regime is only observed in the 2008-09 period for the US and Indian reachable stock index returns. In contrast, the remote stock index returns moves back to a calm regime more rapidly, though it also returns to a crisis state in a short period.

The present study on equity market contagion is limited to testing the transmission of the crisis based on the reachability factor from the US to the Indian market. Extending the study to the other markets, for example by analyzing the Eurozone Debt Crisis considering the reachability factor, is worth exploring. Contagion has relevance for optimal asset allocation, risk measurement, and investment diversification. Understanding how the important decisions taken on these factors can be better informed by considering contagion as a factor remains unexplored. A further limitation of the study is that it could not consider how the bond market responds to crisis transmission. Investigating stock returns (both reachable and remote) and government bond index return comovement during calm and crisis periods would assist in understanding the spread of the crisis between risky and safe assets. An additional investigation into the impact of policy interventions on reachability factor in preventing or speeding up contagion is also an avenue for future research. 


\section{Acknowledgements}

We are grateful to the two anonymous reviewers for their constructive comments on the earlier version of this paper. Further, I acknowledge that the present study is a part of my unpublished PhD dissertation.

\section{Authors' contributions}

RS contributed to the development of the conceptual idea and SS contributed to the development of the model. Both authors read and approved the final manuscript.

\section{Authors' information}

Ms. Rajan Sruthi is a Doctoral Candidate in the Department of Commerce, School of Management, Pondicherry University. She has qualified M.com and MBA in Finance. Dr. Santhakumar Shijin is an Assistant Professor in the Department of Commerce, School of Management, Pondicherry University. Dr. Shijin has PhD degree in Finance.

\section{Funding}

No specific source of funding.

Availability of data and materials

The datasets used and/or analyzed during the current study can be provided on reasonable request.

\section{Competing interests}

We declare that we don't have any competing interests.

Received: 26 March 2019 Accepted: 7 May 2020

Published online: 19 May 2020

\section{References}

Abeysinghe T, Forbes K (2005) Trade linkages and output-multiplier effects: a structural VAR approach with a focus on Asia. Rev Int Econ 13(2):356-375

Ahmad W, Sehgal S (2015) Regime shifts and volatility in BRIICKS stock markets : An asset allocation perspective. Int J Emerg Mark 10(3):383-408

Aloui R, Ben Aissa MS, Nguyen DK (2011) Global financial crisis, extreme interdependences, and contagion effects: the role of economic structure? J Bank Financ 35(1):130-141

Ang A, Bekaert G (2002) International asset allocation with regime shifts. Rev Financ Stud 15(4):1137-1187

Ang A, Chen J (2002) Asymmetric correlations of equity portfolios. J Financ Econ 63(3):443-494

Bae KH, Karolyi GA, Stulz RM (2003) A new approach to measuring financial contagion. Rev Financ Stud 16(3):717-763

Baele L (2005) Volatility spillover effects in European equity markets. J Financ Quant Anal 40(2):373-401

Baig T, Goldfajn I (1999) Financial market contagion in the Asian crisis. IMF Staff Pap 46(2):167-195

Barlevy G, Veronesi P (2003) Rational panics and stock market crashes. J Econ Theory 110(2):234-263

Baur D (2003) Testing for contagion-mean and volatility contagion. J Multinatl Financ Manag 13(4-5):405-422

Baur DG (2012) Financial contagion and the real economy. J Bank Financ 36(10):2680-2692

Bekaert G, Ehrmann M, Fratzscher M, Mehl A (2014) The global crisis and equity market contagion. J Financ 69(6):2597-2649

Bekaert G, Harvey CR, Ng A (2005) Market integration and contagion. J Bus 78(1):39-69

Bertero E, Mayer C (1990) Structure and performance: global interdependence of stock markets around the crash of October 1987. Eur Econ Rev 34(6):1155-1180

Billio M, Duca ML, Pelizzon L (2005) Contagion detection with switching regime models: a short and long run analysis. GRETA working paper: 05.01, Venice. Retrieved from https://ssrn.com/abstract=676956 or https://dx.doi.org/https://doi.org/10. 2139/ssin.676956

BIS (2009) The international financial crisis: timeline, impact and policy responses in Asia and the Pacific. Bank for International Settlements, Basel

Boamah NA, Watts EJ, Loudon G (2017) Financial crisis, the real sector and global effects on the African stock markets. Q Rev Econ Finance 65(August):88-96

Bollerslev T (1986) Generalized autoregressive conditional heteroskedasticity. J Econ 31(3):307-327

Boyer BH, Kumagai T, Yuan K (2006) How do crises spread? Evidence from accessible and inaccessible stock indices. J Financ 61(2):957-1003

Breuss F (2011) Global financial crisis as a phenomenon of stock market overshooting. Empirica 38(1):131-152

Butler KC, Joaquin DC (2002) Are the gains from international portfolio diversification exaggerated? The influence of downside risk in bear markets. J Int Money Financ 21(7):981-1011

Calomiris CW, Love I, Martinez Peria MS (2012) Stock returns' sensitivities to crisis shocks: evidence from developed and emerging markets. J Int Money Financ 31(4):743-765

Calvo GA (1999) Contagion in emerging markets: when wall street is a carrier. In: Bour E, Heymann D, Navajas F (eds) Latin American economic crises: trade and labour. Palgrave Macmillan, New York, NY, pp 81-91

Calvo S, Reinhart C (1996) Capital flows to Latin America: is there evidence of contagion effects? Policy research working paper no: WPS 1619. World Bank, Washington, DC

Cappiello L, Engle RF, Sheppard K (2006) Asymmetric dynamics in the correlations of global equity and bond returns. J Financ Econometrics 4(4):537-572

Celik S (2012) The more contagion effect on emerging markets: the evidence of DCC-GARCH model. Econ Model 29(5):19461959

Chan KS, Chao C, Chou WL (2002) Trade similarities and contagion among the Asian crisis economies. J Asian Econ 13(2): 271-283

Chan-Lau JA, Mathieson DJ, Yao JY (2004) Extreme contagion in equity markets. IMF Staff Pap 51 (2):386-408 
Chao X, Kou G, Peng Y, Alsaadi FE (2019) Behavior monitoring methods for trade based money laundering integrating macro and micro prudential regulation: a case from China. Technol Econ Dev Econ 25(6):1081-1096

Chesnay F, Jondeau E (2001) Does correlation between stock returns really increase during turbulent periods? Econ Notes 30(1):53-80

Chiang TC, Jeon BN, Li H (2007) Dynamic correlation analysis of financial contagion: evidence from Asian markets. J Int Money Financ 26(7):1206-1228

Chollete L, de la Pena V, Lu CC (2011) International diversification: a copula approach. J Bank Financ 35(2):403-417

Chuhan P, Claessens S, Mamingi N (1998) Equity and bond flows to Latin America and Asia: the role of global and country factors. J Dev Econ 55(2):439-463

Claessens S, Dell'Ariccia G, Igan D, Laeven L (2010) Lessons and policy implications from the global financial crisis. IMF working paper no: WP/10/44. International Monetary Fund, Washington, DC

Claessens S, Dornbusch R, Park YC (2001) Contagion: why crisis spread and how this can be stopped. In: Claessens S, Forbes $\mathrm{KJ}$ (ed) international financial contagion. United States: springer science + business media, LLC, pp 19-41.

Connolly RA, Wang FA (2000) On stock market return co-movements: macro economic news, dispersion of beliefs, and contagion. Working paper, University of North Carolina: Chapel Hill. Availble via https://ssrn.com/abstract=233924 or http://dx.doi.org/https://doi.org/10.2139/ssrn.233924.

Connolly RA, Wang FA (2003) International equity market comovements: economic fundamentals or contagion? Pacific Basin Finance J 11(1):23-43

Corsetti G, Pesenti P, Roubini N (1999) What caused the Asian currency and financial crisis? Jap World Econ 11(3):305-373

Dimitriou D, Kenourgios D, Simos T (2013) Global financial crisis and emerging stock market contagion: a multivariate FIAPARCH-DCC approach. Int Rev Financ Anal 30(December):46-56

Dungey M, Fry R, Gonzalez-Hermosillo B, Martin VL, Tang C (2010) Are financial crises alike ? IMF working paper no: WP/10/14

Eichengreen B, Rose AK, Wyplosz C (1996) Contagious currency crises. NBER working paper no. 5681:1-48. Available via http:// www.nber.org/papers/w5681

Engel C, Hamilton JD (1990) Long swings in the dollar: are they in the data and do markets know it? Am Econ Rev 80(4): $689-713$

Engle RF (1982) Autoregressive conditional heteroskedasticity with estimates of the variance of United Kingdom inflation. Econometrica 50(4):987-1007

Fama EF (1963) Mandelbrot and the stable paretian hypothesis. J Bus 36(4):420-429

Federal Reserve Board of St. Louis (2009) The financial crisis: a timeline of events and policy actions. FRBS, St. Louis

Forbes K, Rigobon R (2001) Contagion in Latin America: definitions, measurement, and policy implications. Economia 1(2):1-46

Forbes KJ (2002) Are trade linkages important determinants of country vulnerability to crisis? NBER working paper, pp 77-130. University of Chicago. Available via http://www.nber.org/chapters/c10634.pdf

Forbes KJ, Rigobon R (2002) No contagion, only interdependence: measuring stock market comovements. J Financ 57(5): 2223-2261

Fry R, Martin VL, Tang C (2010) A new class of tests of contagion with applications. J Bus Econ Stat 28(3):423-437

Furman J, Stiglitz JE, Bosworth BP, Radelet S (1998) Economic crisis: evidence and insights from East Asia. Brook Pap Econ Act 1998(2):1-135

Gallegati M (2012) A wavelet-based approach to test for financial market contagion. Comput Stat Data Anal 56(11):3491-3497

Gennotte G, Leland H (1990) Market liquidity, hedging, and crashes. Am Econ Rev 80(5):999-1021

Glick R, Rose AK (1999) Contagion and trade: why are currency crisis regional? J Int Money Financ 18(4):603-617

Gravelle T, Kichian M, Morley J (2006) Detecting shift-contagion in currency and bond markets. J Int Econ 68(2):409-423

Guillen MF (2009) The global economic and financial crisis: a timeline. University of Pennsylvania, The Lauder Institute, pp 1-91

Guo F, Chen CR, Huang YS (2011) Markets contagion during financial crisis: a regime switching approach. Int Rev Econ Financ 20(1):95-109

Guyot A, Lagoarde-Segot T, Neaime S (2014) Foreign shocks and international cost of equity destabilization. Evidence from the MENA region. Emerg Mark Rev 18(March):101-122

Hamao Y, Masulis RW, Ng V (1990) Correlations in price changes and volatility across international stock markets. Rev Financ Stud 3(2):281-307

Hamilton JD (1989) A new approach to the economic analysis of nonstationary time series and the business cycle. Econometrica 57(2):357-384

Hamilton JD, Susmel R (1994) Autoregressive conditional heteroskedasticity and changes in regime. J Econ 64(1-2):307-333

Hartmann P, Straetmans S, Vries CG (2004) Asset market linkages in crisis periods. Rev Econ Stat 86(1):313-326

Hon MT, Strauss JK, Yong SK (2007) Deconstructing the NASDAQ bubble: a look at contagion across international stock markets. J Int Financ Mark Inst Money 17(3):213-230

Hong H, Stein JC (2003) Differences of opinion, short-sales constraints, and market crashes. Rev Financ Stud 16(2):487-525

Horta P, Lagoa S, Martins L (2016) Unveiling investor-induced channels of financial contagion in the 2008 financial crisis using copulas. Quant Finance 16(4):625-637

Hwang E, Min HG, Kim BH, Kim H (2013) Determinants of stock market co-movements among US and emerging economies during the US financial crisis. Econ Model 35(September):338-348

Idier J (2011) Long-term vs. short-term comovements in stock markets: the use of Markov-switching multifractal models. Eur J Financ 17(1):27-48

Jaffee DM (2008) The U.S. mortgage subprime crisis: issues raised and lessons learned. Working paper no: 28, commission on growth and development, Washington, DC.

Jin X, An X (2016) Global financial crisis and emerging stock market contagion: a volatility impulse response function approach. Res Int Bus Financ 36(January):179-195

Jondeau E, Rockinger M (2006) The copula-GARCH model of conditional dependencies: An international stock market application. J Int Money Financ 25(5):827-853

Kali R, Reyes J (2010) Financial contagion on the international trade network. Econ Inq 48(4):1072-1101. https://doi.org/10. 1111/j.1465-7295.2009.00249.x 
Kaminsky G, Lyons RK, Schmukler SL (2004) Managers, investors, and crisis: mutual fund strategies in emerging markets. J Int Econ 64(1):113-134

Kaminsky GL, Lyons RK, Schmukler SL (2001) Mutual fund investment in emerging markets: An overview. World Bank Econ Rev 15(2):315-340

Kaminsky GL, Reinhart CM (2000) On crisis, contagion, and confusion. J Int Econ 51(1):145-168

Karolyi GA, Stulz RM (1996) Why do markets move together? An investigation of U.S.-Japan stock return comovements. J Financ 51(3):951-986

Karunanayake I, Valadkhani A, O'Brien M (2010) Financial crisis and international stock market volatility transmission. Aust Econ Pap 49(3):209-221

Kenourgios D (2014) On financial contagion and implied market volatility. Int Rev Financ Anal 34(July):21-30

Kenourgios D, Christopoulos A, Dimitriou D (2013) Asset markets contagion during the global financial crisis. Multinational finance journal $17(1 / 2): 49-76$.

Kenourgios D, Dimitriou D (2015) Contagion of the global financial crisis and the real economy: a regional analysis. Econ Model 44(January):283-293

Kenourgios D, Padhi P (2012) Emerging markets and financial crises: regional, global or isolated shocks? J Multinatl Financ Manag 22(1-2):24-38

Kenourgios D, Samitas A, Paltalidis N (2011) Financial crises and stock market contagion in a multivariate time-varying asymmetric framework. J Int Financ Mark Inst Money 21(1):92-106

Kim CJ, Nelson CR, Startz R (1998) Testing for mean reversion in heteroskedastic data based on Gibbs-sampling-augmented randomization. J Empir Financ 5(2):131-154

King M, Sentana E, Wadhwani S (1994) Volatility and links between National Stock Markets. Econometrica 62(4):901-933

King MA, Wadhwani S (1990) Transmission of volatility between stock markets. Rev Financ Stud 3(1):5-33

Kodres LE, Pritsker M (2002) A rational expectations model of financial contagion. J Financ 57(2):769-799

Kosmidou K, Kousenidis D, Ladas A, Negkakis C (2019) Do institutions prevent contagion in financial markets? Evidence from the European debt crisis. Eur J Financ 25(7):632-646

Kosmidou KV, Kousenidis DV, Negakis CI (2015) The impact of the EU/ECB/IMP bailout programs on the financial and real sectors of the ASE during the Greek sovereign crisis. J Bank Financ 50(January):440-454

Kou G, Chao X, Peng Y, Alsaadi FE, Viedma EH (2019) Machine learning methods for systemic risk analysis in financial sectors. Technol Econ Dev Econ 25(5):716-742

Kyle AS, Xiong W (2001) Contagion as a wealth effect. J Financ 56(4):1401-1440

Lakshmi P, Visalakshmi S, Shanmugam K (2015) Intensity of shock transmission amid US-BRICS markets. Int J Emerg Mark 10(3):311-328

Leung H, Schiereck D, Schroeder F (2017) Volatility spillovers and determinants of contagion: exchange rate and equity markets during crises. Econ Model 61(February):169-180

Longin F, Solnik B (2001) Extreme correlation of international equity markets. J Financ 56(2):649-676

Majid MSA, Kassim SH (2009) Impact of the 2007 US financial crisis on the emerging equity markets. Int J Emerg Mark 4(4): 341-357

Mandelbrot B (1963) The variation of certain speculative prices. J Bus 36(4):394-419

Mandilaras A, Bird G (2010) A Markov switching analysis of contagion in the EMS. J Int Money Financ 29(6):1062-1075

Masson P (1999) Contagion: macroeconomic models with multiple equilibria. J Int Money Financ 18(4):587-602

N'Diaye P, Zhang P, Zhang W (2010) Structural reform, intra-regional trade, and medium-term growth prospects of East Asia and the Pacific-perspectives from a new multi-region model. J Asian Econ 21(1):20-36

Neaime S (2016) Financial crises and contagion vulnerability of MENA stock markets. Emerg Mark Rev 27(June):14-35

Ning C (2010) Dependence structure between the equity market and the foreign exchange market-a copula approach. J Int Money Financ 29(5):743-759

Okimoto T (2008) New evidence of asymmetric dependence structures in international equity markets. J Financ Quant Anal 43(3):787-815

Patton A (2009) Copula-based models for financial time series. In: Andersen TG, Davis RA, Kreiss JP, Mikosch T (eds) Handbook of financial time series. Springer, New York, NY, pp 767-786

Patton AJ (2006) Modelling asymmetric exchange rate dependence. Int Econ Rev 47(2):527-556

Pelletier D (2006) Regime switching for dynamic correlations. J Econ 131(1-2):445-473

Pericoli M, Sbracia M (2003) A primer on financial contagion. J Econ Surv 17(4):571-608

Petmezas D, Santamaria D (2014) Investor induced contagion during the banking and European sovereign debt crisis of 2007-2012: wealth effect or portfolio rebalancing? I Int Money Financ 49(B):401-424

Radelet S, Sachs J (1998b) The onset of the east Asian financial crisis. NBER working paper no: 6680. Available via http://www. nber.org/papers/w6680

Radelet S, Sachs JD (1998a) The east Asian financial crisis: diagnosis, remedies and prospects. Brook Pap Econ Act 1998(1):1-74

Ramchand L, Susmel R (1998) Volatility and cross correlation across major stock markets. J Empir Financ 5(4):397-416

Rigobon R (2003) On the measurement of the international propagation of shocks: is the transmission stable? J Int Econ 61(2):261-283

Rodriquez JC (2007) Measuring financial contagion: a copula approach. J Empir Financ 14(3):401-423

Romer D (1993) Rational asset price movements without news. Am Econ Rev 83(5):1112-1130

Sun W, Rachev S, Fabozzi FJ, Kalev PS (2009) A new approach to modeling co-movement of international equity markets: evidence of unconditional copula-based simulation of tail dependence. Empir Econ 36(February):201-229

Turner CM, Startz R, Nelson CR (1989) A Markov model of heteroskedasticity, risk, and learning in the stock market. J Finan Econ 25(1):3-22

Valdes R (1997) Emerging markets contagion: evidence and theory. Documentos de Trabajo del Banco Central, Central Bank of Chile

Van Rijckeghem C, Weder B (2001) Sources of contagion: is it finance or trade? J Int Econ 54(2):293-308

Van Rijckeghem C, Weder B (2003) Spillovers through banking centers: a panel data analysis of bank flows. J Int Money Financ 22(4):483-509 
Xue Y, He Y, Shao X (2012) Butterfly effect: the US real estate market downturn and the Asian recession. Financ Res Lett 9(2): 92-102

Yang J, Hsiao C, Li Q, Wang Z (2006) The emerging market crisis and stock market linkages: further evidence. J Appl Econ 21(6):727-744

Yang J, Kolari JW, Min I (2003) Stock market integration and financial crisis: the case of Asia. Appl Financ Econ 13(7):477-486 Yuan K (2005) Asymmetric price movements and borrowing constraints: a rational expectations equilibrium model of crisis, contagion, and confusion. J Financ 60(1):379-411

\section{Publisher's Note}

Springer Nature remains neutral with regard to jurisdictional claims in published maps and institutional affiliations.

Submit your manuscript to a SpringerOpen ${ }^{\circ}$ journal and benefit from:

- Convenient online submission

- Rigorous peer review

- Open access: articles freely available online

High visibility within the field

- Retaining the copyright to your article

Submit your next manuscript at $\boldsymbol{\nabla}$ springeropen.com 